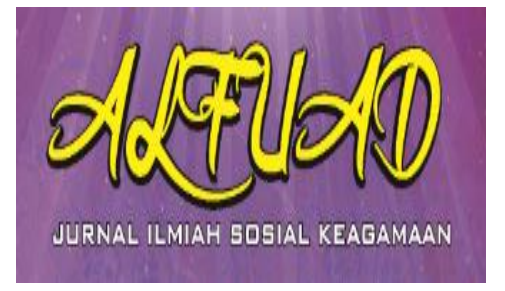

ALFUAD JOURNAL, 2 (2), 2018, (59-71)

(Print ISSN 2614-4786)

Available Online at

http://ecampus.iainbatusangkar.ac.id/ojs/index.php/alfuad

\title{
KERJASAMA PENYULUH AGAMA ISLAM FUNGSIONAL DENGAN APARAT KELURAHAN DALAM MENGATASI PENYAKIT MASYAKARAKAT DI KELURAHAN PURUS KECAMATAN PADANG BARAT KOTA PADANG
}

\author{
Syafriwaldi \\ Institut Agama Islam Negeri Batusangkar \\ Indonesia \\ E-mail: syafriwaldi583@gmail.com
}

\begin{abstract}
This paper raises the problem of how the cooperation of the Functional Islamic Counselor with Urban Officials in overcoming the disease of the community in Purus Village, Padang Barat Subdistrict, Padang City. Limitation of research is Cooperation extension of Islam functional with the village officials in overcoming drugs. Religious and village officials face many problems, such as multi talent community, stubborn, unruly and so on. Departing from the background above, it needs an in-depth study of the Cooperation of Functional Islamic Counselor with Urban Officials in Overcoming Community Disease. This research is a descriptive field research, aiming to describe reality in the field with qualitative and rationalistic approach. Data source 19 people Extension of Islamic Religion Functional PNS and Non PNS, Official apparatus, community leaders in Purus Village. Cooperation of extension of functional Islam with the urban village apparatus in overcoming drugs in Purus urban village only oriented to preventive measures. There is no action or curative cooperation.
\end{abstract}

Keywords: Drugs, Dakwah, Religious Instructors, Purus

\section{PENDAHULUAN}

Penyuluh agama Islam fungsional adalah Pegawai Negeri Sipil yang diberi tugas, tanggung jawab, wewenang dan hak secara penuh oleh pejabat yang berwenang untuk melaksanakan bimbingan atau penyuluhan agama dan pembangunan kepada masyarakat melalui bahasa agama (Departemen Agama RI, 2000: 61). Eksistensi penyuluh agama fungsional sangat urgen dalam masyarakat. Mereka adalah orang-orang yang memberikan penerang kepada masyarakat baik dalam bidang agama maupun bidang pembangunan.

Berbagai persoalan yang muncul dalam kehidupan masyarakat seperti perbedaan agama, status sosial, ekonomi yang bisa jadi bergeser ke ranah konflik, baik antara individu, kelompok, maupun antar komunitas masyarakat itu sendiri. Padahal masyarakat merupakan wadah atau tempat dimana masyarakat bisa mewujudkan 
pergaulan hidup yang saling berhubungan interaksi secara timbal balik. Ketidakmampuan manusia dalam beradaptasi dengan lingkungannya (maladjustment), maka keadaan yang seperti itu oleh Gillin dan Gillin disebut sebagai "social disorganization atau social pathology" (Kartini Kartono, 1992: 1).

Berdasarkan obervasi awal, penyakit masyarakat yang menjadi tantangan dakwah Islam yang terjadi di Kelurahan Purus Kecamatan Padang Barat adalah sebagai berikut: Kriminalitas seperti: terjadinya perkelahian antar pemuda dengan memakai senjata tajam, baik internal di rukun tetangga/ rukun warga (RT/RW) maupun antar pemuda di luar rukun tetangga/ rukun warga (RT/RW), bahkan sampai meninggal dunia, kejadian ini hampir tiap tahun.

Pemakai dan pengedar ganja, sabusabu, inex, atau disebut juga dengan narkoba. Perjudian yang diawali seperti permainan domino dikedai-kedai hampir di setiap RT/RW yang berbuntut perkelahian dan meminum minuman keras. Pemasang dan pengedar togel atau kupon putih dan sejenisnya. Pencurian kotak infak masjid, pungutan liar dan pemalakkan oleh anak di bawah umur.

Melihat keberadaan penyakit masyarakat yang bertentangan dengan norma-norma agama dan adat istiadat, sehingga rusaknya nilai sosial yang ada dalam lingkungan masyarakat Purus, tentu saja tidak bisa dibiarkan begitu saja harus ada pihak yang bertanggung jawab atau yang berkompeten, diantaranya adalah aparat kelurahan, pihak berwajib apalagi penyuluh agama Islam yang tugasnya amar ma'ruf nahi munkar (mengajak kepada yang baik dan mencegah kemungkaran).

Oleh karena itu kerjasama semua lini terutama Penyuluh Agama Islam (PNS dan Non PNS) dan aparat lainnya sangatlah penting dan strategis untuk membawa masyarakat kepada jalan kebenaran (jalan Allah), di samping melaksanakan penyuluhan juga memberikan penerangan dan motivasi terhadap pelaksanaan programprogram pembangunan kepada masyarakat (Departemen Agama RI, 2003: 10).

Hal ini juga berarti bahwa dakwah tidak hanya semata-mata menyadarkan manusia agar ia taat menjalankan ibadah mahdhah atau sekedar peningkatan pemahaman keagamaan individu tetapi harus lebih dari itu, yakni pelaksanaan ajaran Islam dalam segala aspek kehidupan, sehingga terwujudnya situasi yang lebih baik dan sempurna dalam masyarakat. Sebagaimana pendapat al-Yasa Abu Bakar yang dikutip oleh Muhammad Sulthon menyatakan bahwa fungsi dakwah itu adakalanya I'tiyadi, (mengembalikan kepada tatanan nilai keIslaman), Muharriq (peningkatan nilai-nilai ke-Islaman yang sudah ada), Iqaf (Upaya preventif berupa petunjuk dan peringatan agar mereka tidak terjerumus pada hal-hal 
yang tidak Islami) dan Tahrif. (Muhammad Sulthon, 2003: 140).

Melihat penyakit masyarakat yang melanggar, mengganggu masyarakat dan merugikan orang banyak, penyuluh agama yang telah ditugaskan bertanggung jawab penuh terhadap wilayah kerjanya dan semestinya lebih memaksimalkan upaya dalam pembinaan umat serta meningkatkan kerjasamanya. Apalagi penyuluh agama Islam dan aparat kelurahan bagaikan dua sisi mata uang yang tidak dipisahkan dalam mengatasi penyakit masyarakat. Sebab antara keduanya adalah tenaga teknis perpanjangan tangan pemerintah yang ditugaskan negara.

Namun kenyataan di lapangan tidak sedikit tugas-tugas penyuluh yang terabaikan sebagai gambaran dari rendahnya kerjasama sebahagian besar penyuluh fungsional. Apabila hal ini dibiarkan tetap seperti ini, tentu saja akan merugikan kepada masyarakat dan pemerintah selaku institusi yang mengangkatnya.

\section{TINJAUAN KEPUSTAKAAN}

\section{Pengertian Kerjasama}

Menurut Zainudin dalam website www.etd.library.ums.ac.id kerjasama merupakan kepedulian satu orang atau satu pihak dengan orang atau pihak lain yang tercermin dalam suatu kegiatan yang menguntungkan semua pihak dengan prinsip saling percaya, menghargai dan adanya norma yang mengatur, makna kerjasama dalam hal ini adalah kerjasama dalam konteks organisasi, yaitu kerja antar anggota organisasi untuk mencapai tujuan organisasi (seluruh anggota).

Sedangkan Menurut Pamudji, Kerjasama pada hakekatnya mengindikasikan adanya dua pihak atau lebih yang berinteraksi secara dinamis untuk mencapai suatu tujuan bersama (Pamudji, 1985: 12-13). Dalam pengertian itu terkandung tiga unsur pokok yang melekat pada suatu kerangka kerjasama, yaitu unsur dua pihak atau lebih, unsur interaksi dan unsur tujuan bersama. Jika satu unsur tersebut tidak termuat dalam satu obyek yang dikaji, dapat dianggap bahwa pada obyek itu tidak terdapat kerjasama.

Unsur dua pihak, selalu menggambarkan suatu himpunan yang satu sama lain saling mempengaruhi sehingga interaksi untuk mewujudkan tujuan bersama penting dilakukan. Apabila hubungan atau interaksi itu tidak ditujukan pada terpenuhinya kepentingan masing-masing pihak, maka hubungan yang dimaksud bukanlah suatu kerjasama. Suatu interaksi meskipun bersifat dinamis, tidak selalu berarti kerjasama. Suatu interaksi yang ditujukan untuk memenuhi kepentingan pihak-pihak lain yang terlibat dalam proses interaksi, juga bukan suatu kerjasama. Kerjasama senantiasa menempatkan pihak- 
pihak yang berinteraksi pada posisi yang seimbang, serasi dan selaras.

\section{Konsep Kerjasama dalam Islam}

Kerjasama sering disebut al musyarakah. Istilah lain dari al musyarakah adalah syirkah atau syarikah. Musyarakah adalah kerjasama antara kedua belah pihak untuk memberikan kontribusi dana dengan keuntungan dan resiko akan ditanggung bersama sesuai dengan kesepakatan. (Heru Sudarsono, 2007: 67).

Secara bahasa syirkah berarti campur. Sedangkan menurut syara' ialah tetapnya hak atas dasar memasukkan sesuatu yang satu untuk dua orang, bahkan lebih banyak (Muhammad Bin Qasim Al Ghazy, 1991: 384). Kata Syirkah dalam bahasa arab berasal dari kata syarika (fiil madhi), yasyraku (fill mudhari'), syarikan/syirkatan/syarikatan (mashdar) kata dasar), artinya menjadi sekutu atau serikat.

\section{Hukum Syirkah dalam Islam}

Syirkah hukumnya ja'iz atau mubah, berdasarkan dalil Hadis Nabi SAW. Berupa taqrir / pengakuan beliau terhadap syirkah. Pada saat beliau diutus sebagai Nabi, masyarakat pada zaman itu telah bermuamalah dengan cara ber-syarikah dan Nabi membenarkannya. Nabi SAW bersabda, sebagaimana dituturkan Abu Hurairah RA: “Allah Azza Wa Jalla telah berfirman: AKU adalah pihak ketiga dari dua pihak yang ber-syarikah selama salah satunya tidak menghianati yang lainnya. Jika salah satunya berkhianat, aku keluar dari keduanya" (HR. Imam Daruquthni dari Abu Hurairah r.a), (Muhammad Ismail Yusanto, 2002: 134).

\section{Penyuluh Agama Islam Fungsional}

Penyuluh berasal dari kata Suluh yang artinya: barang yang dipakai untuk menerangi. Sedangkan Penyuluh berarti pemberi penerangan; penunjuk jalan (Departemen Pendidikan dan kebudayaan, 1995: 970). "Penyuluh" juga merupakan arti dari kata bahasa Inggris “counseling”, yang sering diterjemahkan dengan "menganjurkan atau menasehatkan" (Depertemen Agama RI, 2010: 5).

Adapun yang dimaksud dengan penyuluh agama sebagaimana tercantum dalam Keputusan Menteri Agama RI Nomor 791 tahun 1985, adalah "Pembimbing umat beragama dalam rangka pembinaan mental, moral dan ketaqwaan kepada Tuhan Yang Maha Esa, dan Penyuluh Agama Islam, yaitu pembimbing umat Islam dalam rangka pembinaan mental, moral dan ketaqwaan kepada Tuhan Yang Maha Esa, Allah SWT, serta menjabarkan segala aspek pembangunan melalui pintu dan bahasa agama" (Depertemen Agama RI, 2007: 8-9).

Dengan demikian, penyuluh agama Islam adalah para juru penerang penyampai pesan bagi masyarakat mengenai prinsip- 
prinsip dan etika nilai keberagamaan yang baik.

Tugas pokok Penyuluh Agama adalah melakukan dan mengembangkan kegiatan bimbingan Penyuluh agama dan pembangunan melalui bahasa Agama. Pada dasarnya tugas fungsional Penyuluh Agama adalah bersifat mandiri, namun untuk kelancaran dan keberhasilan tugasnya, maka seorang Penyuluh Agama harus melakukan sinergi dan kerjasama yang baik dengan berbagai pihak, instansi dan lembaga yang memiliki keterkaitan secara langsung maupun tidak langsung dengan kegiatan Penyuluh Agama.

\section{Sasaran Penyuluh Agama Islam}

Di dalam kehidupan masyarakat kelompok sasaran ada yang sudah terbentuk dan ada yang belum terbentuk, bagi kelompok sasaran yang sudah terbentuk akan memudahkan seorang penyuluh agama memberikan bimbingan dan penyuluhan, tetapi apabila kelompok sasaran tersebut sudah ada pengelolanya atau penyuluhnya, maka perlu dibentuk kelompok sasaran lainnya.

Sebelum melakukan penyuluhan maka seorang penyuluh agama harus mampu melakukan memetakan kelompok sasaran. Hal ini dikarenakan tidak mungkin seorang penyuluh agama dapat melakukan kegiatan yang menyentuh semua strata dan segmen masyarakat dalam waktu yang bersamaan.
Pemetaan kelompok sasaran dilakukan untuk memudahkan penyuluh agama dalam memilih metode pendekatan dan menentukan materi bimbingan atau penyuluhan yang relevansi dan sesuai dengan kebutuhan kelompok sasaran.

Dalam melakukan pemetaan kelompok sasaran penyuluhan agama Islam, ada beberapa hal pokok yang menjadi tolak ukur dan kerangka analisis yaitu: (1) Kelompok masyarakat dilihat dari tingkatan sosial ekonominya. (2) Kelompok masyarakat dilihat dari tingkatan pendidikan dan pengetahuannya. (3) Kelompok masyarakat dilihat dari statusnya. (4) Kelompok masyarakat dilihat dari segi wilayah/ geografis dan profesinya (Departemen Agama RI, 2002:10)

\section{Patologi Sosial (Penyakit Masyarakat)}

Jika kata patologi dihubungkan dengan kata sosial atau masyarakat sehingga menjadi "patologi sosial" akan berarti sebagai "tentang asal-usul dan sifat-sifatnya penyakit yang berhubungan dengan hakekat adanya manusia dalam hidup bermasyarakat". Manusia dalam hidupnya selalu berusaha untuk menyempurnakan diri, menyesuaikan diri, dengan masyarakat dan alam lingkungannya.

Selanjutnya Gillin dan Gillin memberikan batasan pengertian tentang Social pathology dalam bukunya Cultural Sociology; Patologi sosial ialah suatu kajian 
tentang disorganisasi sosial atau maladjustment yang di dalamnya dibahas tentang arti luas, sebab-sebab, hasil-hasil, dan usaha-usaha perbaikan atau mengobati faktor-faktor yang dianggap dapat mengganggu atau mengurangi penyesuaian sosial (social adjustment), sperti kemiskinan, pengangguran, lanjut usia, penyakit rakyat, lemah ingatan/ pikiran, kegilaan, kejahatan, kekerasan, perceraian, pelacuran, ketegangan-ketegangan dalam keluarga, dan sebagainya (S. Imam Asyari, 1992:11).

Patologi sosial ialah semua tingkah laku yang bertentangan dengan norma kebaikan, stabilitas lokal, pola kesederhanaan, moral, hak milik, solidaritas kekeluargaan, hidup rukun bertetangga, disiplin, kebaikan dan hukum formal (Kartini Kartono, 1992: 1). Atau disebut juga penyakit-penyakit masyarakat atau keadaan abnormal pada suatu masyarakat (Vembriarto, 1985: 5).

Dengan demikian dapat diketahui bahwa yang menjadi lapangan kajian atau penyelidikan patologi sosial ialah problema kemasyarakatan yang timbul sebagai hasil interaksi manusia yang tidak mencapai kesempurnaan sehingga menimbulkan rusaknya nilai-nilai sosial disebabkan adanya tingkah laku yang salah. Masalah sosial yang dimaksud ialah semua bentuk tingkah laku yang melanggar atau memperkosa adatistiadat masyarakat dan adat istiadat tersebut diperlukan untuk menjamin kesejahteraan hidup bersama), atau situasi sosial yang dianggap oleh sebagian besar oleh warga masyarakat sebagai mengganggu, tidak dikehendaki, berbahaya dan merugikan orang lain (banyak).

Masalah sosial berupa; korupsi, perampokan, kemiskinan, gelandangan, pelacuran, keberandalan, anak jalanan, kejahatan (bidang seksual), pencurian, minuman keras, perjudian, kekerasan (KDRT), narkotika (kecanduan obat), kenakalan remaja, penyakit-penyakit mental, dan sebagainya. Ketika manusia itu tidak mampu menyempurnakan dan menyesuaikan dirinya dalam masyarakat dan alam lingkungannya, maka akan menjadi patologi sosial. Disinilah letaknya eksistensi, urgensi dan peranan dakwah yaitu untuk menagajak kepada keinsafan, atau usaha mengubah situasi kepada yang lebih baik terhadap pribadi maupun masyarakat (M. Quraisy Shihab, 1997: 194). Dakwah juga mendorong manusia berbuat kebajikan dan petunjuk, menyuruh mereka berbuat yang ma'ruf dan melarang yang munkar agar mereka mendapat kebahagiaan di dunia dan di akhirat (Salmadanis, 2004:19).

Dakwah merupakan mengajak manusia dengan cara bijaksana kepada jalan yang benar sesuai dengan perintah Tuhan untuk kemaslahatan dan kebahagiaan mereka di dunia dan di akhirat (Thoha Jahya Omar, 1967:1). Agar manusia itu mampu menyesuaikan dan memyempurnakan 
dirinya dan mampu menghadapi tantangan dan hambatan serta keluar dari problematika sosial yang mengancam kehidupannya dalam masyarakat.

\section{METODE}

Jenis Penelitian ini adalah penelitian lapangan (field research) dengan mengumpulkan data dari fenomena yang terjadi langsung, wajar dan alamiah (natural setting). Penulis juga melakukan pendekatan kepustakaan (library research) dengan membaca karya-karya yang terkait dengan persoalan yang akan dikaji. Kemudian mencatat bagian yang memuat kajian tentang penelitian (Mestika Zed, 2007: 3)

Sumber data adalah penyuluh agama Islam fungsional kecamatan Padang Barat yang berjumlah 20 orang.

Pengumpulan data dilakukan dengan cara Wawancara, yang ditujukan kepada Kepala Kantor Urusan Agama (KUA) Kecamatan Padang Barat dengan menggunakan wawancara umum. Wawancara secara mendalam (indept interview) dilakukan terhadap informan yang banyak tahu tentang masalah yang akan diteliti yaitu Penyuluh agama Islam fungsional. Observasi yaitu pengamatan atau penginderaan langsung terhadap benda, kondisi, situasi, proses atau prilaku (Sanapiah Faisal, 2005:52). Studi dokumentasi, yaitu metode pengumpulan data yang digunakan dalam metodologi penelitian sosial untuk menelusuri data historis (M. Burhan Bungin, 2008:121).

Setelah data terkumpul maka dianalisa melalui berbagai proses, yaitu: menyeleksi data, mereduksi, mengkla-sifikasikan, membaca atau memberi kode terhadap datadata tersebut dan terakhir mendiskripsikan data untuk mendapatkan maksud dan makna sesuai dengan tujuan penelitian Lexy J. Moleong, 2007:103).

Untuk menguji keabsahan data diadakan teknik triangulasi (cross cheek) antara lain triangulasi sumber dan teori yang terkait dengan penelitian ini, juga menguji kebenaran data yang diperoleh melalu wawancara dengan data yang diperoleh dari observasi serta data dari studi dokumentasi. Proses triangulasi dilakukan terus menerus sepanjang proses pengumpulan data dan analisa data, sampai diyakini bahwa sudah tidak ada lagi perbedaan, dan tidak ada lagi yang perlu dikonfirmasikan kepada informan. Triangulasi juga dilakukan dengan menguji pemahaman peneliti dengan pemahaman informan (M. Burhan Bungin, 2003:192). Metode ini penulis terapkan di saat merumuskan tentang Penerapan juklak/ juknis yang menjadi acuan pelaksanaan tugas penyuluh.

Untuk menambah masukan dan kritikan, peneliti mendiskusikan dengan rekan-rekan kepala seksi dan kepala kantor urusan agama kecamatan yang disebut 
dengan istilah "pemeriksaan sejawat" melalui diskusi. Selanjutnya diadakan pengkategorian data berdasarkan pertanyaan-pertanyaan yang diajukan, terakhir diadakan editing kepada tiap-tiap data, lalu dianalisis dan ditafsirkan datadata tersebut sebagai hasil penelitian.

\section{PEMBAHASAN}

Kelurahan Purus terletak di kecamatan Padang Barat Kota Padang $0^{0} .58$ ' lintang selatan dan $100^{0} .21^{\prime} .11^{\prime}$ ” Bujur Timur (BPS Padang, 2008:3) Kelurahan Purus memiliki luas wilayah $38 \mathrm{Ha}$. Sebelah utara berbatas dengan kelurahan Rimbo Kaluang, sebelah selatan berbatas dengan kelurahan Olo, dan sebelah barat berbatas dengan Samudera Hindia serta sebelah timur berbatas kelurahan Padang Pasir (Statistik Lurah Purus, 2010).

Jumlah penduduk 7.165 orang dengan rincian menurut jenis kelamin laki-laki 3.544 dan perempuan 3.621. Jumlah yang memiliki Kartu Keluarga (KK) 1.649 orang dengan kewarganegaraan Indonesia (WNI). Sedangkan jumlah penduduk menurut agama terbagi dalam 5 (lima) agama yakni: yang memeluk agama Islam berjumlah 7.032 orang, Khatolik 100 orang, Protestan sebanyak 21 orang, Budha sebanyak 11 orang dan penduduk masyarakat Purus tidak ada yang memeluk agama Hindu.

Tidak banyak masyarakat Purus yang menjadi nelayan, hal terbukti dari 7.165 orang penduduk hanya 139 orang yang mempunyai mata pencaharian sebagai nelayan. Pegawai negeri berjumlah 191 orang, ABRI 15 orang, swasta 619 orang, buruh sebanyak 76 orang, pensiunan sebanyak 115 orang, sedangkan 1.332 orang didominasi oleh masyarakat wiraswasta.

Monografi kelurahan Purus mendeskripsikan bahwa jumlah penduduk berdasarkan tingkat pendidikan menunjukkan bahwa di kelurahan Purus tidak banyak penduduk yang menyentuh pendidikan perguruan tinggi. Hal ini dibuktikan dengan data hanya 462 orang dari 7.165 orang jumlah penduduk. Tingkat SD dan SLTA lebih mendominasi yakni 1048 orang dan SLTA 2138 orang. Rupanya juga ada masyarakat yang tidak sampai ke pendidikan sekolah dasar (SD) yaitu hanya sampai TK (Taman Kanak-kanak) sebanyak 124 orang, dan yang terakhir tingkat akademi berjumlah 257 orang.

\section{Kerjasama Penyuluh Agama Islam} Fungsional Dengan Aparat Kelurahan Dalam Mengatasi Narkoba Di Kelurahan Purus Kecamatan Padang Barat Kota Padang.

Kelurahan Purus menjadi daerah yang strategis untuk melakukan mengkonsumsi narkoba, karena daerah Purus daerah yang nyaman untuk pelarian bagi pelaku narkoba. Dilihat daerah geografisnya daerah Purus terdiri dari jalan-jalan yang menghubungkan dua jalan utama (jalan Sudirman dan jalan 
Samudera Hindia). Sehingga jika terjadi penggerebekan yang telah di TO (target operasi) oleh polisi, pelaku dengan mudah menghilangkan jejak dengan cara memasuki jalan pintas untuk melarikan diri. Daerah Purus hanya dipisahkan oleh jalan pintas antar jalan Sudirman dan jalan Samudera Hindia. (Jalan pintas dibagi menjadi 6, yaitu jalan Purus I, Purus II, Purus III, Purus IV, Purus V dan Purus VI, yang masing jalan itu sepanjang 500-600 meter).

Pemakai ganja, Mardi (45 tahun) memaparkan ia menjadi pemakai sudah 6 tahun, yang diperoleh dari temannya Ben (43 tahun) yang sudah menjadi pecandu selama 7 tahun. Kalau tidak dapat menghirup atau mengisap ganja maksimal satu minggu maka kepala menjadi pusing, pikiran kacau, dan rasa badan tidak enak. Apalagi kalau terjadi masalah pribadi atau keluarga maka rasanya ingin membunuh setiap orang yang bertemu dengannya (Mardian, 2013). Dengan adanya ganja tersebut sangat membantu untuk meredakan masalah yang ada walaupun tidak akan mampu menyelesaikan masalah tersebut.

Berbicara tentang pemakai narkoba di kelurahan Purus berdasarkan observasi dan wawancara menunjukkan bahwa tidak adanya pendataan terinci baik tentang pemakai itu sendiri maupun pecandu narkoba. Hal ini disebabkan karena penanganan kasus hanya bersifat preventif dan tidak bersifat kuratif (Muhsin Husin,
2013). Penanganan atau tindakan hanya dilakukan ketika ada pengaduan masyarakat atau mendapat instruksi oleh pihak terkait yaitu institusi Kepolisian, pamong praja, atau badan sosial lainnya. Dalam hal ini aparat kelurahan hanya sebagai fasilitator perpanjangan tangan dari pihak yang berkompeten.

Tindakan aparat kelurahan Purus terhadap pecandu narkoba hanya berbentuk tindakan pencegahan tidak langsung, seperti upaya sosialisasi bahaya narkoba, penyuluhan terhadap penyalahgunaan narkoba (Muhsin husin, 2013) itu pun tidak dilakukan terhadap pemakai tetapi terhadap generasi remaja dalam konteks acara-acara tertentu. Misalnya ketika acara wirid remaja, pesantren ramadhan, dan lain-lain.

Dalam penyuluhan dan langkah antisipasi, aparat kelurahan juga bekerja sama dengan Badan Narkotika Nasional (BNK) Kota Padang dan pihak Kepolisian dan Penyuluh Agama dalam hal ini penyuluh agama Islam (Johardi, 2013). Kemudian meminta peran serta masyarakat untuk melaporkan jika di wilayah Purus ada kedapatan memakai, mengedar, pecandu narkoba.

Ketua BNK Kota Padang dalam pelantikan Satgas Anti-Narkota di SMA 9 Padang. Membebaskan lingkungan sekolah dari narkotika dan obat-obat terlarang (narkoba), Pemko Padang melantik 400 
Satgas Anti-Narkoba dari kalangan pelajar SMA dan SMK (Fauzi Bahar, 2013).

Fauzi Bahar mengungkapkan, pembentukan Satgas Anti-Narkoba ini untuk mewujudkan lingkungan sekolah yang bebas dari narkoba. Pembentukan satgas di kalangan pelajar ini, diharapkannya, tidak sekadar seremonial saja, tapi fungsinya benar-benar harus dimaksimalkan. Minimal mereka bisa menjadi motivator dalam upaya pencegahan penyalahgunaan narkoba di lingkungan sekolah dan keluarga masingmasing.

Data penyalahgunaan narkoba di kalangan pelajar cukup memprihatinkan. Tahun 2011 pelajar di Kota Padang yang terlibat narkoba mencapai 9 orang. Sebanyak 6 orang ditahan pada tahun 2012, dan hingga Maret 2013 ada 2 orang pelajar yang terlibat narkoba. Untuk itu, perlu tindakan antisipatif, preventif dan protektif dalam memberantas peredaran narkoba yang merambah pelajar ini.

Ketua Bhayangkari Polda Sumbar ikut mendukung program Pemko Padang ini. Kata Damayanti Wahyu Indra Pramugari, Bhayangkari dan Direktorat Narkoba Polda Sumbar akan memberikan pengetahuan kepada para satgas ini tentang narkoba dan dampaknya.

Tindakan yang dilakukan BNK setidaknya telah membuahi hasil. Dengan adanya penyuluhan narkoba setidaknya berharap sudah mengurangi angka pemakai dan pecandu di kelurahan Purus. Ironisnya semakin dilakukan penyuluhan narkoba semakin bertambah jumlah pemakai. Hal ini dibuktikan dalam data kriminal Polsek Padang Barat bahwa selama dua bulan terakhir tertangkap 4 orang pemakai narkoba di kelurahan Purus (Desniwati, 2013). Tertangkap dengan nama Jhon Kapak (39 tahun), Robby Aciak (37 tahun), Rizaldo Mamak (35 tahun), Leo Lumuik (44 tahun) dan telah dijatuhi hukuman 5 tahun kurungan penjara. Sedangkan pada tahun 2012 sampai awal tahun 2013 hanya terdapat 2 orang pemakai dan pecandu yang tertangkap dengan nama Yudhi Spartak (29 tahun) dan Inyiak Bujang (47 tahun), (Idwan, 2013)

BNK juga menghimbau kepada masyarakat Purus bahwa siapa yang melihat, mendengar informasi tentang adanya pemakai dan pengedar Narkoba di kelurahan Purus kiranya warga melaporkan ke BNK sendiri, bisa ke Lurah, ke Babinkamtibmas Purus.

Aiptu Sukasmi dari Bimas Polresta Padang juga mengulas, pengguna dan pengedar Narkoba akan mendapatkan sangsi yang berat sesuai dengan hukum yang berlaku. Untuk memberantas peredaran dan penggunaan Narkoba kita memerlukan informasi dari masyarakat. Penyalahgunaan Narkoba baik pengedar ataupun pengguna akan mendapat hukuman berat sesuai dengan aturan perundangan-undangan yang berlaku di negara ini. Hukuman terberat bagi 
pengedar dan pengguna Narkoba adalah hukuman mati (Aiptu Sukasmi, 2013).

Berbeda pula kiranya tindakan yang dilakukan oleh penyuluh agama Islam Kecamatan Padang Barat Kota Padang. Kegiatan dilakukan ketika ada permintaan dari pihak kelurahan untuk menyampaikan penyuluhan ditinjau dari sisi agama. Kegiatan bisa dalam bentuk ceramah, khotbah, pidato, pelatihan, pemberdayaan, life skill, muhasabah (Harwan Kasri, 2013).

Dengan demikian tergambar bahwa kerjasama antara aparat kelurahan dengan penyuluh agama dalam pemberantasan narkoba berorientasi pada langkah-langkah preventif. Terkesan sekali tidak tampak kerjasama yang bersifat aksi atau kuratif. Hanya saja kegiatan penyuluhan berbeda dari sudut pandang keilmuan dan tugas pokok tenaga teknis (tupoksi) di lingkungan atau institusi tempat bekerja. Kalau aparat kelurahan memberikan penyuluhan dari pandangan hukum ketatanegaraan yang berlaku, sedangkan penyuluh agama Islam memberikan penyuluhan dari sudut pandang ilmu keislaman.

\section{KESIMPULAN}

Kerjasama antara aparat kelurahan dengan penyuluh agama dalam mengatasi narkoba berorientasi pada langkah-langkah preventif. Tidak tampak kerjasama yang bersifat aksi atau kuratif. Kegiatan dilakukan ketika ada permintaan dari pihak kelurahan untuk menyampaikan penyuluhan ditinjau dari sisi agama. Kegiatan dilakukan dalam bentuk himbauan, ceramah, khutbah, pidato, pelatihan, pemberdayaan, life skill, muhasabah. Kegiatan tersebut hanya dilakukan di masjid-masjid dan mushalla yang sudah ditunjuk oleh kelurahan Purus.

Jika dilihat dari segi bentuk kerjasama itu sendiri, maka kerjasama yang dilakukan antara penyuluh agama Islam dengan aparat kelurahan tidaklah ada karena tidak mencakup atau tidak memenuhi unsur-unsur teori kerjasama yang ada yang telah penulis paparkan pada bab landasan teoritis sebelumnya.

Kepada penyuluh agama Islam Fungsional agar terlibat dalam peberantasan narkoba. Pemerintah kota Padang, mohon tertibkan pedagang yang berjualan di tepi laut Purus, karena tempat tersebut dijadikan sarana transaksi narkoba. Aparat keamanan agar tidak tebang pilih dalam penegakan hukum.

\section{DAFTAR PUSTAKA}

Abd-Rosyad, S. (1993). Manajemen Dakwah Islam. Jakarta: Bulan-Bintang.

Abd-Rosyad, S. (2000). Prinsip Dasar Metode Dakwah. Jakarta: Minangkabau Foundation.

Ali Aziz, M. (2004). Ilmu Dakwah. Jakarta: Prenada Media.

Ali, M. (t.th). Hidayah Al-Mursyidin dan AlMa'arif. Beirut.

Anshari, H. E. S. (1986). Wawasan Islam. Jakarta: Rajawali Pers.

Anshary, I. (1995). Mujahid Da'wah. Bandung: CV. Diponegoro. 
Arifin, H. (1997). Psikologi Dakwah. Jakarta: Bulan Bintang.

Arifin, M. (1994). Psikologi Dakwah- Suatu Pengantar. Jakarta: Bumi Aksara.

Awiskarni, dkk. (2003). Capita Selekta Ilmu Dakwah I. Jakarta: PT. Kartika Insan Lestari.

Bachtiar, W. (1997). Metode Penelitian Ilmu Dakwah. Jakarta: Logos.

Departemen Agama RI. (1992). Pola Pembinaan Lembaga Keagamaan Islam. Jakarta: Proyek Pembinaan Keagamaan.

Departemen Agama RI. (2000). Himpunan Peraturan tentang Jabatan Fungsional Penyuluh Agama dan Angka Kreditnya. Jakarta: Direktorat Jendral Bimbingan Masyarakat Islam dan Urusan Haji.

Departemen Agama RI. (2003). Buku Panduan Pelaksanaan Tugas Penyuluh Agama. Dirjen Kelembagaan Agama Islam.

Departemen Pendidikan Nasional. (2002). Kamus Besar Bahasa Indonesia. Jakarta: Balai Pustaka.

Furchan, A. (1992). Pengantar Metode Penelitian Kualitatif. Surabaya: Penerbit Usaha Nasional.

Habib, M. S. (1982). Buku Pedoman Dakwah. Jakarta: PT. Bumi Restu.

Hadi, M. S. (t.th). Rahasia Keberhasilan Dakwah K. H. Zainuddin MZ. Surabaya: Apel Suci.

Hadi, S. (1989). Metodologi Research. Yogyakarta: Andi Ofset.

Hadi, S. (1989). Metodologi Research. Yogyakarta: Andi Ofset.

Hafiduddin, D. (1998). Dakwah Aktual. Jakarta: Gema Insani Press.

Hasanuddin, A. H. (1982). Retorika Dakwah dan Publisistik. Surabaya: Usaha Nasional.

Hasanuddin. (1966). Hukum Dakwah. Jakarta: Ilmu Jaya.

Hasibuan, M. S. P. (2007). Manajemen Sumber Daya Manusia. Jakarta: Bumi Aksara.

Hasjmy, A. (1994). Dustur Dakwah menurut al-Qur'an. Jakarta: Bulan Bintang.
Hasnawirda. (1999). Ilmu Dakwah. Padang: IAIN IB Press.

IAIN Imam Bonjol. (2007). Buku Pedoman Penulisan Karya Ilmiah. Padang.

Kaffie, J. (1998). Pengantar Ilmu Dakwah. Surabaya: Karunia.

Karni, A. (2004). Dakwah Islam dan Dinamika Masyarakat. Jakarta: The Minangkabau Foundation.

Khaidir, K. B. (1993). Ilmu Dakwah. Bukittinggi: Pustaka Indonesia.

Latif, N. H. M. S. (1971). Teori dan Praktek Dakwah Islamiyah. Jakarta: Firman Dara.

Leliweri, A. (2003). Dasar-dasar Komunikasi Antar Budaya. Yogyakarta: Pustaka Pelajar.

Ma'luf, L. (1997). Al-Munjid fi al-Lughat. Dar al Masyriq: Beirut.

Mahfuz, K. (1975). Filsafat Dakwah dan Penerapannya. Jakarta: Bulan Bintang.

Maraghi, A. M. (t.th). Tafsir al-Maraghi. Beirut: Dar al-Ihyai Turas al-Arabi.

Marzuki. (19890. Metodologi Research. Yogyakarta: Fakultas Ekonomi UII.

Masyhur, M. A. (1997). Dakwah Islam dan Pesan Moral. Jakarta: Al-Amin Press.

Mueller, D. J. (1992). Mengukur Sikap Sosial. Jakarta: Bima Aksara.

Muhaimin, S. (1998). Prinsip-Prinsip Metodologi Dakwah. Surabaya: Usaha Nasional.

Muhammad, A. (2005). Komunikasi Organisasi. Jakarta: PT Bumi Aksara.

Mulyadi, Y. (1999). Antropologi. Jakarta: Departemen Pendidikan dan Kebudayaan.

Munayi, A. K. (1987). Media dalam Dakwah. Jakarta: CV Bayu Pratama.

Natsir, M. (1998). Fiqhud Dakwah. Jakarta; Media Dakwah.

Patton, Q. M. (1987). Qualitative Evaluation Methods. Baverly Hills: Sage Publication.

Poerwardaminta, W. J. S. (2003). Kamus Umum Bahasa Indonesia. Jakarta: Balai Pustaka.

Qardawi, Y. (1997). Pengantar Kajian Islam. Jakarta: Pustaka al-Kautsar. 
Rafi'iudin \& Djaliel, M. A. (1997). Prinsip dan Strategi Dakwah. Bandung: Pustaka Setia.

Rafi'uddin, M. A. D. (1997). Prinsip dan Strategi Dakwah. Bandung: Pustaka Setia.

Rahmat, J. (1998). Psikologi Komunikasi. Bandung: PT Remaja Rosdakarya.

Robbins, J. G. (1986). Komunikasi yang Efektif, Jakarta: Pedoman Ilmu Jaya.

Romly, A. M. (1999). Medan dan Bahan Dakwah. Jakarta: CV. Multi Yasa.

Rukminto, I. R. (2003). Pemberdayaan Dan Pengembangan Masyarakat Dan Intervensi Komunitas. Jakart: lembaga Penerbit FE UI.

Rusli, M. (2000). Ilmu Komunikasi Suatu Pengantar. Jakarta: The Minangkabau Foundation.

Salim, P. \& Salim, Y. (1991). Kamus Bahasa Indonesia Kontemporer. Jakarta: Modern English Press.

Salmadanis. (2003). Filsafat Dakwah. Jakarta: Surau.

Setiana, L. (2005). Teknik Penyuluhan dan Pemberdayaan Masyarakat. Bogor: Galia Indonesia.

Shidiq, S. (1987). Dakwah dan Teknik Berkhutbah. Bandung: Al-Ma'arif.

Sukayat, T. (2009). Quantum Dakwah. Jakarta: Rineka Cipta.

Sulistiyani, T. A. (2004). Kemitraan dan Model Pemberdayaan. Jogyakarta: Gaya Media.

Sulthon, M. (2003). Desain Ilmu Dakwah, Kajian Ontologis, Epistemologis dan Aksiologis. Semarang: Wali Songo Press.

Sumantri, J. S. (2003). Filsafat ilmu sebuah Pengantar Popular. Jakarta: Pustaka Sinar Harapan.

Suminto, A. (1984). Problematika Dakwah. Jakarta: PT. Pustaka Panjimas.

Suparta, M. dkk. (2006). Metoode Dakwah. Jakarta: Kencana.

Suryabrata, S. (1990). Metodologi Penelitian. Jakarta: Rajawali Press.

Syihab, M. Q. (2004). Membumikan AlQuran, Fungsi dan Peran Wahyu dalam Kehidupan Masyarakat. Bandung: Mizan.

Syukir, A. (1987). Dasar-dasar Strategi Dakwah Islam. Surabaya: Al-Ikhlas.

Tasmara, H. T. (2003). Komunikasi Dakwah. Jakarta: GMP.

Team Dosen Fakultas Dakwah IAIN IB Padang. (2003). Capita Selecta Ilmu Dakwah. Jakarta: Kartika Insan Lestari.

Thahir, M. H. (1984). Pengantar Ilmu Dakwah. Proyek Pembinaan Perguruan Tinggi IAIN Ar-Raniri, Banda Aceh.

Tono, S. dkk. (1998). Ibadah dan Akhlak dalam Islam. Yogyakarta: YUU Press Indonesia.

Wibowo. (2009). Manajemen Kinerja. Jakarta: Rajawali Pers.

Widjaja, H. A. W. (1993). Komunikasi dan Hubungan Masyarakat. Jakarta: Bumi Aksara.

Widjaja, H. A. W. (1998). Ilmu Komunikasi Pengantar Studi. Jakarta: PT Renika Cipta.

Wursanto, I. G. (1998). Etika Komunikasi Kantor. Jakarta: Komisius.

Ya'cub, H. (1981). Publistik Islam Seni dan Teknik Dakwah. Bandung: CV Diponegoro.

Yunus, M. (1981). Pedoman Dakwah Islamiyah. Jakarta: PT Hida Karya Agung.

Yunus, M. (1989). Kamus Arab-Indonesia. Jakarta: P.T. Hida Karya Agung.

Zaidillah, A. I. (2002). Strategi Dakwah Dalam Membentuk Da'i dan Khatib Profesional. Jakarta: Kalam Mulia. 